\title{
The Development of Intellectual Property Policies in Africa- Some Key Considerations and a Research Agenda
}

\section{Caroline B Ncube*}

Senior Lecturer, Department of Commercial Law, University of Cape Town, South Africa

\begin{abstract}
This paper considers factors that are relevant to recent efforts to formulate Intellectual Property Policies in Africa following the adoption of the Development Agenda by the World Intellectual Property Organisation (WIPO). It highlights the need to develop policies tailored for each country's socio-economic status and the need to use evidence to ensure a rigorous policy approach. It also considers WIPO's technical assistance may be more effectively used by African states in their policy processes and concludes with a research agenda intended to stimulate critical engagement with these key issues.
\end{abstract}

Keywords: Africa; Economic development; Intellectual property; Policy; Evidence; Technical assistance; WIPO; ARIPO

\section{Introduction}

In the last decade African states have become more involved in the global Intellectual Property (IP) law system, with their most auspicious moment being the adoption of the World Intellectual Property Organisation (WIPO)'s Development Agenda (DA) in 2007 [1-3]. Since the adoption of the WIPO DA several projects have been initiated in Africa with a view to enhancing development through appropriately calibrated IP systems. These systems are crafted through legislation thus making IP legislation and the policies that inform it the focal area for analysis of IP systems.

In an ideal world, legislation is informed by a thoroughly researched policy that has been comprehensively consulted upon. Many African states' reality is far from this ideal as they have IP legislation that they inherited from their colonizers and have had to review to comply with the Agreement on Trade Related Aspects of IP Rights (TRIPS) [4] without the benefit of meaningful policy formulation. It is only now that these states are currently formulating their IP policies with a view to amending their existing IP frameworks. For example, amongst the members and observers of the African Regional Intellectual Property Organisation (ARIPO), several countries including South Africa and Zimbabwe are currently in the policy formulation process. In order to achieve appropriately balanced IP regimes that best serve the public interest, is imperative that the policy formulation be sound. This paper discusses two key considerations to be borne in mind in IP policy formulation, namely socio-economic context and the use of evidence. It also considers how developing countries can effectively leverage WIPO technical assistance in their policy formulation processes and suggests a research agenda for the evaluation of such assistance.

\section{Socio-economic context}

'Laws regulating intellectual property must serve as a means of achieving creative, social and economic ends and not as ends in themselves.'

\section{Principle 1 Adelphi Charter [5]}

One of the key considerations that ought to be borne in mind by IP policy makers is that an IP policy and legal framework ought to be crafted with reference to the relevant country's socio-economic status and goals. It is generally accepted that law is important to economic development and that legal and economic development, among others, are 'constitutive parts of development as a whole' [6]. However, the impact of IP law on economic development is both topical and controversial [7]. Before discussing the relationship between IP law and economic development, it is important to expressly define economic development. The classic definition is that economic development is 'the process by which per capita income and economic welfare of a country improve over time' [8]. The current and more progressive conceptualization of economic development is that it is not only about 'formal economic opportunities' but is about human 'freedoms and capabilities to have basic economic needs fulfilled' $[6,9,10]$. Clearly, the understanding of what constitutes economic development has changed over time, [11-13] as should ways of creating an enabling legal environment.

Some scholars contend that since developed nations have both strong IP protection and strong economies, developing countries need to develop stronger IPR protection in order to enhance economic development [14-17]. This point of view is contestable because it appears to overlook the crucial question of when developed countries created these strong IPR protection systems. Was it before or after they had achieved significant economic growth? Other scholars argue that it was only after developed countries had achieved economic growth that they strengthened their IPR systems [18-21].

This second argument appears to be the more persuasive because it has been shown that in their formative years today's developed countries showed scant regard for IPRs and routinely violated the IPRs of other countries' citizens [22]. For example the US Copyright Act of 1790 did not apply to the works of non-US citizens and protection was only extended to some non-US citizens by the International Copyright Act of 1891 [23].

The same pattern of relying on minimalist IP regulatory systems during periods of steep economic growth is evident today. The

*Corresponding author: Caroline B Ncube, Senior Lecturer, Department of Commercial Law, University of Cape Town, South Africa, Tel: +27216503776; E-mail: caroline.ncube@uct.ac.za

Received February 21, 2013; Accepted April 25, 2013; Published April 27, 2013

Citation: Ncube CB (2013) The Development of Intellectual Property Policies in Africa- Some Key Considerations and a Research Agenda. Intel Prop Rights 1: 101. doi:10.4172/2375-4516.1000101

Copyright: ( 2013 Ncube CB. This is an open-access article distributed under the terms of the Creative Commons Attribution License, which permits unrestricted use, distribution, and reproduction in any medium, provided the original author and source are credited. 
economies of Brazil, Russia, India and China (together with South Africa collectively referred to as the BRICS) [24] which are predicted to become the largest world economies by 2050 [25] are currently on a steep growth curve. Analysis of their IP protection regimes shows that the protection they provide is considerably weaker than that provided by developed nations such as the United States and that they have consistently, but not always successfully, resisted pressure to strengthen their IP protection regimes [26-29].

In particular, it has been shown that China [30-32] and Brazil have minimalist IP protection but are thriving economically. For example, Brazil delayed the provision of patents for pharmaceutical patents until December 2004 but has become 'world's leading supplier of generic medicines' [33]. It is therefore reasonable to conclude that a strong IPR protection system is only of marginal importance to a developing country's economic development.

There appear to be two reasons for this. First, the domestic benefits in the form of increased knowledge generation are likely to be very small as there are very low levels of research and development in developing countries and most of the knowledge generated there is sub - patentable [7]. This is exacerbated by the fact that the infrastructure to support innovation is often lacking. Secondly, the international benefits that are said to flow from strong IP, namely greater technology transfer, Foreign Direct Investment (FDI) and innovative efforts are also minimal [7].

As an example, one can consider South Africa's experience. There is only one in-depth study of the economic impact of IP in South Africa by Kaplan [34]. This study noted that, prior to it, there had been no research exploring the impact of South Africa's IP laws on FDI and technology transfer to South Africa or on 'the broader impact of the IP regime on innovation and economic performance' [35].This study also noted that FDI inflows into South Africa have been minimal. Evidence of this is provided by numerous sources, for example, UNCTAD's Global Investment Trends Monitor No 5 (January 2011) stated that in 2010 South Africa received $\$ 1.3$ billion FDI inflows, whilst Brazil received $\$ 30.2$ billion, China received 101.1 billion (exclusive of the financial sector), India received $\$ 23.7$ billion and Russia received $\$ 39.7$ billion [36]. Kaplan highlighted that these low levels of FDI exist although South Africa already has a relatively strong IP system and has consistently ranked highly in various indices evaluating the strength of national IP systems over the past decade. In 1998 South Africa scored the highest out of a ranking of 44 developing and industrializing countries carried out by Lesser, in 2005 South Africa scored higher than other similarly placed developing countries and even some developed countries on the Ginarte Park Index and in 2008 South Africa ranked 22 out of 115 countries in the Property Alliance's International Property Rights Index (IPRI) [37,38]. By all indications, this trend continues unabated and the Property Alliance's 2011 IPRI ranks South Africa's IP system as number 21 out of 129 countries with a score of 7.3 out of 10 [39].

In contrast to South Africa's placing at 21, the 2011 IPRI ranked Brazil and India at 51 with a score of 5.5 each. China ranked at 59 with a score of 5.2 and Russia ranked at 67 with a score of 5. It is important to highlight that South Africa's IP system is much stronger than her fellow BRICS however as stated above they have received substantially higher FDI inflows than South Africa. The limited FDI inflows into South Africa prove that strong IP does not necessarily translate into stronger flows of FDI. On the other hand, the higher FDI inflows into the other BRICS (with weaker IP systems than South Africa's) demonstrate that weaker IP systems do not have a marked negative impact on FDI inflows. Therefore South Africa would do well to learn from her fellow BRICS and adopt a conservative IP regime which favours minimalism, within the bounds of her international obligations, until national socioeconomic goals have been achieved.

African states need to calibrate their IP policies and laws to enable them to achieve their socio-economic goals. The African Group and the Development Agenda Group (DAG) have emphatically stated that an appropriately balanced or nuanced system that takes a country's socioeconomic condition and development goals into account and not one that is based on a 'one size fits all' and 'IP as an end itself perspective. An example of these statements is Para 7 of the African proposal for the establishment of a development agenda for WIPO (WIPO Doc IIM/3/2 Rev, 31 July 2005) as follows:

'IP is just one mechanism among many for bringing about development. It should be used to support and enhance the legitimate economic aspirations of all developing countries including LDCs, especially in the development of their productive forces, comprising of both human and natural resources. IP should therefore, be complimentary and not detrimental to individual national efforts at development, by becoming a veritable tool for economic growth'.

A second example is Para 1 of the DAG's Guiding Principles (WIPO Doc CDIP/5/9 Rev, 26 April 2010) where the DAG applauded the adoption of the DA as a:

'a milestone in achieving the historic aspiration of developing countries for a paradigm shift in the international perspective of Intellectual Property (IP): a shift from viewing IP as an end in itself, to viewing it as a means to serve the larger public goals of social, economic and cultural development.

This vision has refuted the universal applicability of 'one size fits all IP protection models' or the advisability of the harmonization of laws leading to higher protection standards in all countries irrespective of the levels of development'.

\section{Evidence based policy formulation}

"Government should ensure that development of the IP System is driven as far as possible by objective evidence. Policy should balance measurable economic objectives against social goals and potential benefits for rights holders against impacts on consumers and other interests. These concerns will be of particular importance in assessing future claims to extend rights or in determining desirable limits to rights".

\section{Hargreaves Report, p8: Recommendation 1 [40].}

IP Policy formulation is conflicted terrain, because the policy agenda is contested by numerous stakeholders including government, civil society, the private sector, donors and fellow members of regional or international alliances to which a country belongs. There are numerous stakeholders because IP impacts several distinct spheres including health, education, food security and trade. Therefore coordination and clarity is essential to the policy formulation process. Evidence, which consists of facts, expert opinion and stakeholder views and experiences, will also be required to determine how to nuance an IP policy. Using evidence leads to a cogent, thorough and methodical approach and results in policy that is more appropriate or balanced [41].

It is essential to be clear about what constitutes good evidence, as it is only such evidence that should be considered by policy makers. The 
United Kingdom's Intellectual Property Office (UK IP Office) has issued Guidelines on standards that have to be met by evidence submitted to it. These Guidelines state that the UK IP Office's aim is that 'evidence used to inform public policy, or intended to inform government, meets the following three criteria: that it be clear, verifiable and able to be peer-reviewed.' Clarity in this context refers to clear language, an unequivocal statement of assumptions underlying the evidence, precise calculations, comprehensible graphics, as well as transparency about funding sources and modes of implementation. The data that is being presented as evidence must be verifiable. Similarly, it must be possible to validate any surveys and the analysis thereof. Ideally, such analysis and the conclusions based on it ought to have been subjected to a peer review process.

Sourcing evidence is also an important aspect of the generation of evidence based policy. Evidence typically comes from four sources. First, it may be commissioned by policy makers in accordance with applicable procurement laws and processes. Secondly, it may be volunteered by interested parties during public consultation.

Third, it may be generated by research carried out by government departments. Finally it may be the result of research conducted by independent research projects. Due to its differing origins, evidence usually exists or is presented in many different forms. For example, it may be a formal written scholarly output written by experts or it may be oral anecdotal evidence presented by a layperson at a public consultative meeting. Policy makers therefore need to carefully consider how much weight will be given to each type of evidence presented to them [41].

Southcliffe and Court point out that evidence is relevant at all stages of the policy formulation process to assist those involved in the policy process to [41] -

1. Understand the dynamic policy environment;

2. Assess the probable consequences of policy adjustments;

3. Reveal the connections between 'strategic direction, intended outcomes and policy objectives', to demonstrate the efficacy of policy suggestions;

4. Establish the necessary steps towards achieving strategic goals or intermediate objectives and

\section{Garner support for policy suggestions.}

States involved in IP policy formulation ought to do their utmost to ensure that they use evidence to support their policy options and final recommendations. Some states may lack the resources to obtain the necessary expert evidence. It is suggested that such states rely on technical assistance provided by relevant developmental agencies to fund or prepare the expert research. Whilst many agencies are in a position to offer such support, the most directly relevant agency appears to be WIPO as IP is its field of specialty. However, care needs to be taken, when this course is followed as discussed below.

\section{Effectively leveraging WIPO technical assistance - the research agenda}

Some African states are embarking on policy formulation with the assistance of WIPO under the rubric of DA Recommendation 10 which mandates WIPO:

“ To assist Member States to develop and improve national intellectual property institutional capacity through further development of infrastructure and other facilities with a view to making national intellectual property institutions more efficient and promote fair balance between intellectual property protection and the public interest. This technical assistance should also be extended to subregional and regional organizations dealing with intellectual property."

These states are attempting to reset the course of their IP frameworks (strategies, policies, law and practices) in alignment with their developmental goals. Therefore WIPO's intervention has to be carefully conceptualized and delivered to ensure that this opportunity is well used. Research projects that seek to evaluate such intervention with a view to enhancing it would be useful.

For instance, such research ought to examine how African states are leveraging this assistance from WIPO inthe furtherance of their socio-economic goals. In particular, how WIPO capacity building tools have been crafted and how African countries are using them. The two following initiatives are of immediate interest:

1. Development Agenda Project DA_10_05

This project has been completed in six countries, namely Algeria, Dominican Republic, Mali, Moldova and Tanzania. Its objective was the creation of tools to be used in the policy making cycle [42].

2. The WIPO Director General led Framework on Designing National IP

Strategies [43] under which WIPO has recently rolled out an IP Policy Toolkit.

The content, implementation and coordination of WIPO IP policy and strategy capacity building activities have been highlighted as worthy of attention by a recent external review of WIPO technical assistance [44]. Based on an evaluation of activities carried out between 2008 and 2010, the authors of this report made several recommendations for the enhancement of these activities. Follow-up research projects ought to evaluate the extent to which these recommendations have been implemented by WIPO. It would also be beneficial to seek to extend the external review's scrutiny (which did not include country specific analysis) by focusing on at least two African states.

Such country specific analysis is the subject of a case study under the Open African Innovation Research and Training Project (Open AIR) [45]. This Open AIR study focuses on Kenya, Egypt, Mozambique and Ghana and considers all the WIPO DA projects being implemented in these countries. Another source of case studies is regional capacity building delivered through the African Regional Intellectual Property Organisation (ARIPO). For example policymaking was discussed at a meeting held from 5 - 6 November 2012 [46]. Such a focus will be complementary to a case study on francophone African OAPI member states' implementation of the TRIPS Agreement published recently [47].

In addition, research could also consider the effect, if any, WIPO's technical assistance has played in the conceptualization of the Pan African IP Organization (PAIPO). In this context the key enquiry will be how (WIPO incubated) national IP strategies and policies informed African Union (AU) member states' positions with regard to PAIPO and how PAIPO corresponds with the principles that informed the WIPO DA.

There already has been analysis of the Draft PAIPO statute [48-54] but none has specifically interrogated the role played by WIPO. 


\section{Suggested Research Questions}

The key research question that such research ought to address is:

Is the implementation of WIPO IP strategy and policymaking capacity building initiatives in(selected African states) positively impacting the IP framework (strategies, policies, laws and practices) in these countries by enhancing their efforts to realize their socioeconomic goals individually and collectively?

This question sparks the following sub-questions:

1. What is/has been the nature of WIPO IP strategy and policymaking capacity building initiatives in these countries?

2. Are these initiatives compatible with these states' current socioeconomic status and future imperatives?

3. Are these initiatives appropriately realigning current IP strategies and policies (where these exist) with these countries' socioeconomic goals?

4. Do these initiatives promote the balanced treatment of both industrial property and copyright/creative industries?

5. Do these initiatives promote comprehensive expert and public consultation within each state as a basis for strategy and policy?

6. Did African states' IP policies or their collective position with regard to the WIPO DA inform their positions with regard to PAIPO?

The answers to these questions will contribute to the current understanding of how developing countries leverage global institutions' capacity building offerings in the furtherance of their developmental goals. The research findings will seek to complement existing studies, some of which have been mentioned above.

\section{Conclusion}

As many African states engage in IP policy formulation, individually and collectively through existing regional IP organisations, it is important to emphasise how critical appropriately calibrating these policies is. Policies that do not heed socio-economic realities nor rely on sound evidence are doomed to fail because they will not enable states to achieve their socio-economic goals. Existing research has shown that unbalanced policies will not result in the desired economic growth either through FDI or domestic growth. It has shown that policies are better off promoting IP systems that are initially flexible enough to foster innovation and competition and to thereafter incrementally and judiciously increase or strengthen these systems as economies become more mature. This is indeed the approach taken by today's developed nations as they proceeded through various stages of economic growth. The exact calibration of the IP system will have to be based on reliable and credible evidence of the needs or interests of all relevant stakeholders, including creators, users and society generally.

Reliance on technical assistance to ensure that these factors are given their due weight will be inevitable for many states which lack national financial resources and expertise. This then raises the issues of the appropriateness of such assistance and how states can use it effectively. As there is limited existing research on these aspects, this paper has presented a suggested research agenda to illuminate the key aspects of this issue with a view to enabling those who render technical assistance to do so in a more fitting way and to empower those who rely on the assistance to take full and meaningful advantage of it.

\section{References}

1. Beer DJ (2009) Defining WIPO's development agenda. In de Beer, Jeremy (ed) Implementing WIPO's Development Agenda. International Development Research Centre and Wilfrid Laurier University Press, Canada.

2. Musungu SF (2010) The Development Agenda and the Changing Face of the World Intellectual Property Organization (WIPO).

3. Christopher May (2007) The World Intellectual Property Organisation and the Development Agenda. Global Governance 13: 161-170.

4. Agreement on Trade-Related Aspects of Intellectual Property Rights.

5. Royal Society of Arts (2006) Promoting Innovation and Rewarding Creativity: A Balanced Intellectual Property Framework for the Digital Age.

6. Sen A (2000) What is the role of legal and judicial reform in the development process? Proceedings of the Role of Legal and judicial reform in development World Bank Legal Conference 1-29.

7. Chang HJ (2001) Intellectual property rights and economic development historical lessons and emerging issues. Journal of Human Development 2 287-309.

8. Jain TR, Bajaj BK, Gupta A, Sandhu AS (2008) Development economics. New Delhi: VK Publications.

9. Sen A (2000) A decade of human development. J Human Develop 1: 17-23

10. Anand S and Sen A (2000) Human development and economic 28: 2029-2049.

11. Adelman I (1961) Theories of economic growth and development. Stanford University Press Canada.

12. Arndt HW (1989) Economic development: the history of an idea. University of Chicago Press United States.

13. Sen A (1997) Development and thinking at the beginning of the 21st century LSE STICERD. DEDPS 02 1-37.

14. Keith E. Maskus (2000) Intellectual property rights and economic development. Case W Res J Int'L L 32: 471-506.

15. Evenson RE (2000) Comment: Intellectual Property Rights and Economic Development. Case W Res J IntL L 33: 187-190.

16. Maskus KE (2005) Foreign direct investment and technology transfer.

17. Fink C, Maskus KE (2005) Intellectual property and development: lessons from recent economic research.

18. Dutfield G (2003) Intellectual property rights and the life science industries: A Twentieth Century History.

19. Ostergard RLJ (2003) The development dilemma: The political economy of intellectual property rights in the international system.

20. Vaver D (2006) Intellectual property rights: Critical concepts in law.

21. Chang HJ (2002) Kicking Away the Ladder: Development Strategy in Historical Perspective. Anthem Press London.

22. Teljeur E (2002) Intellectual property rights in South Africa: A review.

23. Khan BZ (2011) IPR Commision Study Paper 1a:Intellectual property and economic development: lessons from American and European history.

24. Smith JA (2011) BRIC becomes BRICS: changes on the geopolitica Chessboard. Foreign Policy J.

25. Wilson D, Purushothaman R (2003) Dreaming with BRICs: the path to 2050 .

26. Bird RC (2006) Defending intellectual property rights in the BRIC Economies American Bus Law J 43: 317-363.

27. Bird RC (2007) The impact of coercion on protecting US intellectual property rights in the BRIC economies.

28. Jain SC (2006) Emerging Economies and the Transformation of International Business: Brazil, Russia, India and China (BRICs). 431-451.

29. Bird RC, Cahoy DR (2007) The emerging BRIC economies: lessons from intellectual property negotiation and enforcement. Northwestern J Tech Intellec Pro 5: 400-425.

30. Yu PK (2008) Intellectual Property, Foreign Direct Investment and the China Exception. 
Citation: Ncube CB (2013) The Development of Intellectual Property Policies in Africa- Some Key Considerations and a Research Agenda. Intel Prop Rights 1: 101. doi:10.4172/2375-4516.1000101

Page 5 of 5

31. Jain SC, Bird RC (eds) The Global Challenge of Intellectual Property Rights.153-178.

32. Yu KP (2007) Intellectual property, economic development and the China puzzle. Intellectual Property, Trade and Development Strategies to Optimise Economic Development in a TRIPS Plus Era. 173-220.

33. McIntyre D, Mooney G (2007) Where now with equity? The Economics of Health Equity. Cambridge: Cambridge University Press 249-268.

34. WIPO (2009) The Economics of Intellectual Property in South Africa. Geneva: WIPO.

35. Kaplan D (2009) Intellectual Property Rights and innovation. In South Africa: A framework. In WIPO Eco Int Pro South Africa.

36. UNCTAD Global Investment Trends Monitor No 5.

37. Lesser SW (2001) The Effects of TRIPS Mandated Intellectual Property Rights on Economic Activities in Developing Countries.

38. Property Rights (2008) Alliance International Property Rights Index (IPRI).

39. The Property Alliance's 2011 IPRI.

40. Hargreaves I (2011) Digital Opportunity: A Review of Intellectual Property and Growth.

41. Sutcliffe S, Court J (2005) Evidence-Based Policymaking: What is it? How does it work? What relevance for developing countries?
42. WIPO Methodology and Tools for the Development of National IP Strategies.

43. National IP Strategies Portal

44. Birkbeck CD and Roca S (2011) An external review of WIPO technical assistance in the area of cooperation for development.

45. Adusei P, Bannerman S, Musungu SF, Wanis H (2011) The WIPO Development Agenda and the role of IP in open collaborative innovation and creativity in Africa.

46. ARIPO and WIPO Sub-regional Workshop (2012) Developing National Strategies and Policies: New perspectives on copyright. Harare.

47. Deere C (2009) The implementation game: the TRIPS Agreement and the global politics of intellectual property reform in developing countries 240-286.

48. Ncube C, Laltaika E (2013) A new intellectual property organization for Africa? Journal of Intellectual Property Law and Practice 8: 114-117.

49. Baker B (2012) Proposed Pan-African IP Organization a Terrible Idea.

50. Olivier D (2012) South-South agenda timely as PAIPO receives criticism.

51. Egbuonu K (2012) Pan-Africa Intellectual Property Organisation (PAIPO).

52. Ncube C (2012) Piping up on PAIPO.

53. Moyo S (2012) Furthering debate on PAIPO.

54. Karjiker S (2012) Sizing Up The "Ill-Conceived" PAIPO Draft Statute. 